\title{
Breaking the paradigms of residual categories and neglectable importance of non-used resources; the "vital" traditional knowledge of non-edible mushrooms and their substantive cultural significance
}

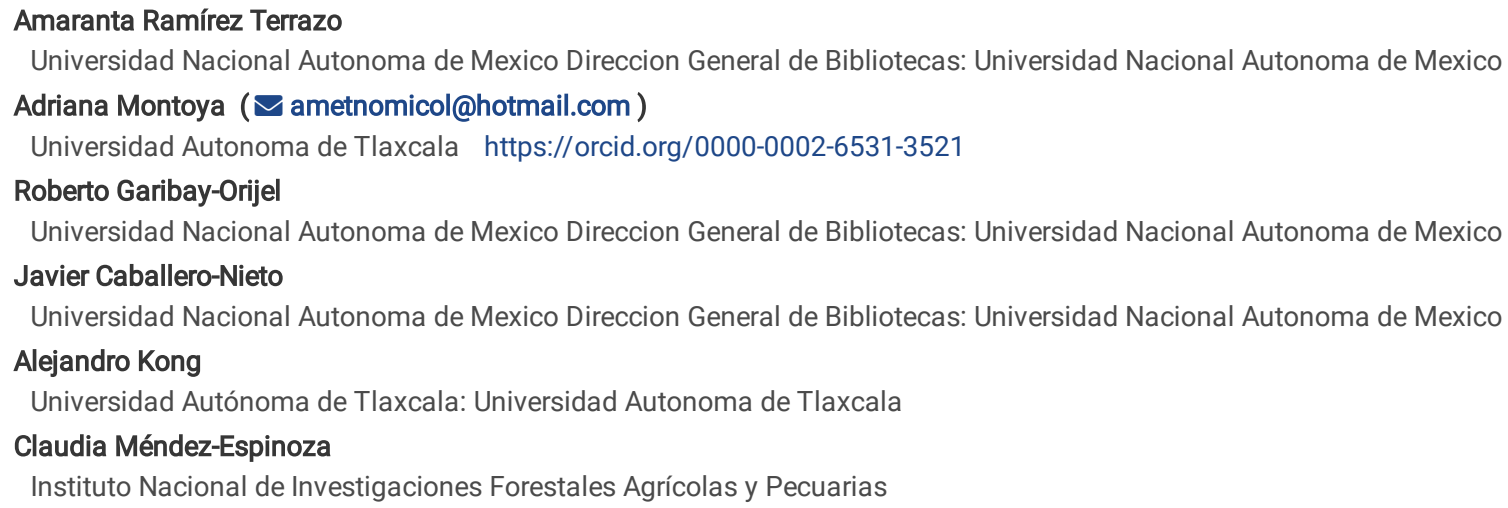

Keywords: non-edible mushrooms, local knowledge, cultural importance, ethnomycology, toxic mushrooms, local classification, non-used resources.

Posted Date: January 5th, 2021

DOl: https://doi.org/10.21203/rs.3.rs-132424/v1

License: (c) (i) This work is licensed under a Creative Commons Attribution 4.0 International License. Read Full License

Version of Record: A version of this preprint was published at Journal of Ethnobiology and Ethnomedicine on April 21st, 2021. See the published version at https://doi.org/10.1186/s13002-021-00450-3. 


\section{Abstract}

Introduction One of the main goals of ethnomycological studies is to understand the role of wild edible mushrooms (WEM) in diverse cultures. To that end, the local knowledge of WEM and their cultural importance are evaluated and compared using qualitative and quantitative methods. However, few studies have attempted to discern such aspects about non-used mushrooms, since they are considered as a residual category without cultural relevance. Therefore, this paper analyses the traditional knowledge of non-edible mushrooms to understand their cultural role and break it down in its components.

Methods This study was carried out in two communities from La Malintzi National Park, Tlaxcala, Mexico. Mushroom species indicated as non-edible were collected during 13 ethnomycological expeditions and 7 requests. To get an insight of local knowledge, we used ethnographic techniques, 91 free listings and 81 semi-structured interviews.

Results In total, we collected 178 specimens of wild mushrooms recognized as non-edible by locals, which corresponded to 103 species belonging to 45 genera. The people who participated in the study had a vast and deep understanding of non-edible mushrooms. To avoid intoxications, all non-edible mushrooms were included in the general category of "poisonous mushrooms". The knowledge and the nomenclature of non-edible mushrooms, as well as the ability to identify them, all emanate from the Mesoamerican duality conceptualization of the universe. Therefore, non-edible species are conceived as a cosmogonic counterpart ("twins") of the edible species to which they resemble. We obtained 101 specific recognition criteria, useful only when comparing species pairs: edible vs non-edible. The most culturally important non-edible groups were differentiated by clear and precise characteristics, which were reflected in the nomenclature and allowed their classification into specific ethnotaxa.

Conclusions We found that non-used resources can be the object of a deep traditional knowledge and have a vast cultural importance. In the case of wild nonedible mushrooms in particular: the species are named, they are the subject of a vast traditional knowledge which is based on the edible/non-edible duality, this knowledge is widespread but has limited consensus, there is little lexical retention, and this knowledge is vital to avoid fatal intoxications. In consequence, deadly species and species that share similarities with the most important edible mushrooms have a high cultural importance.

\section{Background}

In its early stages, ethnobiology was highly utilitarian, with a special interest in natural resources that have a medicinal or dietary potential. Throughout time, this approach has been predominant [1]. Even though living organisms have a meaning beyond the realm of utility [2-4] in terms of local knowledge and cultural importance, species with no use and without local names are commonly ignored in ethnobiological studies [2]. Civilizations build their lore upon people's perception and interpretation of the elements of their environment, supported by their beliefs (kosmos), knowledge (corpus) and practices (praxis) [5].

There is a universal trend within cultures to organize and classify phenomena that can be perceived through lived experiences; therefore, structural guidelines based on comparisons can lead to the identification of groupings [6]. People also recognize the organisms according to common traits. In such sense, morphological similarities and dissimilarities are the basis of ethnobiological classifications, conducting to hierarchical categories that are orally transmitted as local names [7], and it this sense, the aspect of utility is of secondary relevance [8].

On the other hand, since knowledge production requires an energy investment, the knowledge has to be useful and adaptable to be of interest for a given culture [9]. An ethnobiological paradigm has emerged from these points of view: "Useless organisms do not have names and are not classified". This leads to "empty taxonomic spaces", where all non-used species are regrouped under the name "residual categories or residual taxa". These categories encompass among others 1) species that are related to other useful species, 2) rare species, and 3) species with only marginal cultural relevance [8-13].

Modern ethnobiological research indicates that local classification systems are multidimensional, where cognitive, psychological, symbolic, utilitarian and even cosmological aspects interact [3,12]. Within classification systems, there are diverse grouping strategies such as lateral, hierarchical and functional linkages. Altogether, the structure and meaning of the names are fundamental to analyze local classifications [3].

Some ethnomycological studies that have included mushroom species that are either non-edible or have negligible nutritional value, consider them culturally worthless $[11,13-20]$. However, edibility is not an attribute that is inherent to a given species; it is determined by the culinary practices of every culture, by the processing and conservation methods, by the forms and amounts of ingestion, and by symbolic associations $[13,15,17,18]$.

Wild mushroom use is of great nutritional [14,21], economic [22,23], social [24] and cultural importance [25]. Nevertheless, because of toxic species, utilizing wild mushrooms comes with potential risks, even mortal, for non-expert consumers [17,26,27]. Knowledge of these natural resources is mainly possessed and developed by the communities who live in the vicinity of wild mushrooms, but such spaces have changed so much that certain elements that were key to the recognition and identification of toxic and lethal species have been lost, resulting in significant public health risks [16].

The most important classification for wild mushrooms is as edible or non-edible, with the latter considered a residual category [11,13] in which only species that are closely related to notable edible species have names [28]. In many cultures, wild non-edible mushrooms (WNEM) are collectively identified under terms like bol lu' (stupid/crazy mushroom) [13,29,30], pitzunanácatl (non-edible mushrooms) [20,26], lu' (vagina) [10], âh kilo (mushroom) [31], gauku ma dorou (bad gauku) [11], uccan' abe(non-edible mushroom) [2], awo'oh Satan and kiwoh fiyin (non-edible mushroom) [32], or itaikarieya (essence, spirit or ghost) [19].

So far, ethnomycological research has focused on assessing the cultural significance of edible mushrooms [33]; being frequency and order of mention efficient criteria to measure the importance of a mushroom species [34,35]. Garibay-Orijel et al. [36] proposed a Cultural Significance Index for WEM which entails indicators ad hoc to their nature, this index has proven useful to disentangle cultural significance of edible mushrooms [37-40]. On the other hand, studies about the importance of toxic mushrooms are scarce $[13,41]$. They are nonetheless necessary, especially for mycophilic cultures that are exposed to intoxication risks [17,42]. 
Such gaps in knowledge impede the appreciation of the cultural relevance of non-edible and non-used species, among which some species are lethal. Therefore, our main objectives were: a) To highlight the importance of traditional knowledge of non-edible mushrooms; b) To elucidate the nature and structure of such knowledge; and c) To demonstrate the cultural significance of non-edible mushrooms.

\section{Methods}

We used inductive and comparative methods in order to identify patterns of traditional knowledge regarding non-edible mushrooms. Our study was carried out in two communities in central Mexico who share the same biological patrimony. However, although both have indigenous origin, nowadays one is Mestizo (Francisco Javier Mina) and the other is Nahua (San Isidro Buensuceso).

The subjects of this study were non-edible mushrooms. For this purpose, we defined them as the set of mushrooms that are not part of the local diet. Ethnographic, ethnobiological and ethnomycological tools focused on non-edible mushrooms, and data analysis was completed by qualitative and quantitative approaches.

\section{Study sites}

The communities of Francisco Javier Mina and San Isidro Buensuceso, in central Mexico, were selected as study models because its habitants have a broad ethnomycological knowledge $[20,26,33,35,43,44]$. Consequently, we hypothesized that, as both populations know, use and trade edible mushrooms, then they must have a wide notion of the species that are either not consumed, poisonous or a health hazard. Both villages are located in La Malintzi Volcano National Park (PNLM), Tlaxcala, Mexico (Figure 1). Temperate forests with oak, pine and fir trees are characteristic in the Park [45], where 91 edible and 16 toxic mushroom species have been recorded, from which three are lethal: Amanita bisporigera G.F. Atk., A. virosa (Fr.) Bertill. and Galerina marginata (Batsch) Kühner [46].

Francisco Javier Mina (FJM) (19 $\left.11^{\prime} 30^{\prime \prime} \mathrm{N}, 97^{\circ} 55^{\prime} 45^{\prime \prime} \mathrm{W}\right)$ has an altitude of 2,634 m, it belongs to the municipality of Zitlaltépec de Trinidad Sánchez Santos, and is situated on the southeastern slope of the volcano. Founded at the beginning of the XX century, it has 1,114 habitants, $0.27 \%$ of which are indigenous and $0.45 \%$ of which are speakers of an indigenous language [47]. This indicates the loss of indigenous identity. They are manual laborers, housekeepers, traders, and masons, working mostly in Puebla, a neighbor state. During the rainy season, they collect chokecherry and wild mushrooms which are sold by intermediaries in the central markets of the main closest cities [48]

San Isidro Buensuceso (SIBS) $\left(19^{\circ} 09^{\prime} 00^{\prime \prime} \mathrm{N}, 98^{\circ} 06^{\prime} 00^{\prime \prime} \mathrm{W}\right)$ has an altitude of 2,619 m, it belongs to the municipality of San Pablo del Monte, and is situated on the southwestern slope of the volcano. Founded at the end of XIX century [49], the village holds 8,769 people, 73\% of which are bilingual (Nahuatl-Spanish). The rest speak only Nahuatl. They keep many characteristic elements of this indigenous group, despite cultural transformations [50]. Currently, a considerable part or the population travels every day to the municipal seats of Puebla and Tlaxcala to work as masons, manual laborers, bus drivers, porters and seamstresses. Such activities have contributed to transform the social and cultural patterns and so, few people depend on agriculture and forest resources. Nevertheless, during the rainy season, foraging of mushrooms, quelites and other wild plants is an important endeavor among poor families [26].

\section{Data collection and analysis}

In order to get the authorization of civil and traditional authorities, we organized meetings to inform them the nature of the study and our intention to publish the data and images compiled during the research. We also obtained consent from every individual interviewed. Our study was developed according to the code of ethics for research emitted by the Latin American Society of Ethnobiology [51]. In the 2011 and 2012 rainy seasons (May-October), we made 14 visits, six to FJM and eight to SIBS. Every visit lasted from five to seven days. For each visit, we were accompanied by expert mushroom foragers, known as hongueros, (four in FJM and seven in SIBS) [52,53].

We collected non-edible mushrooms during ethnomycological fieldwork with the help of villagers (six in FJM and seven in SIBS). We made two types of excursions: 1) accompanied by hongueros, documenting their procedure to discriminate non-edible mushrooms; 2) accompanied by non-specialist villagers. In total, we traveled on 20 trails corresponding to the sites frequented by people. We observed and recorded the specimens that are usually not collected, neither by hongueros nor by non-specialist villagers, and documented their reactions and attitudes towards such organisms. Then we picked the mushrooms and asked about their specific traits, such as their identification criteria and the name of the edible mushroom to which they perceive a resemblance.

Vouchers were characterized according Cifuentes et al. [54] and Lodge et al. [55]. Taxonomic identification was based on the analysis of micro and macroscopic traits, using taxonomic keys corresponding to particular genus [56-63]. Authors and nomenclature of the species were consulted in Index Fungorum and MycoBank. Specimens were deposited at the herbarium of the Centro de Investigación en Ciencias Biológicas, Universidad Autónoma de Tlaxcala (CICB, UAT).

To evaluate the non-edible mushrooms traditional knowledge, we used ethnographic approximation techniques [64], as well as direct and participant observation $[65,66]$. Field notes records were prioritized and coded [67]. We also executed randomly 18 informal interviews (five in FJM and eight in SIBS), which led us to identify the cultural domains used to construct the semi-structured interviews [68-70].

In a second stage, we conducted randomly 81 semi-structured interviews ( 25 in FJM and 56 in SIBS). The minimum and maximum ages for our interviewees were of 7 and 82 years old. Interviews addressed the following topics, among others: identification criteria, knowledge transmission, uses, types and symptoms of mycetisms, abundance, traditional remedies for mycetisms, perception and attitudes towards mushrooms, and neurotrophic mushrooms. The data obtained was organized in categories, which we further compared in internal and external pairs [71]. Also, we developed a database and calculated the mention percentage for each category. 
To assess the non-edible mushrooms cultural importance (NEMCl), we only considered those mentioned by more than $10 \%$ of our interviewees [26,35]. The $\mathrm{NEMCl}$ indicators were a) declared cultural importance, b) mention frequency, c) rank ordinal value [26,35,36]. Data analysis was performed by means of six basic data matrices [72], from which we estimated frequencies and orders for the next indicators. Mention frequency (MF) was evaluated as a binary qualitative trait: presence (1) and absence (0). For mention order (MO), we used quantitative discrete data $(1,2,3,4,5, \ldots n)[73]$, with which we calculated the rank ordinal value $(\mathrm{ROV})$ :

$$
\mathrm{OVR}_{\mathrm{spi}}=\sum_{i=1}^{n} 1 / p
$$

Where $p$ is the place in the order of the participant's free listing, $i$ is the ethnotaxa spi, and $n$ is the number of people that mentioned $s p i[26,38]$. For the species present in both communities, we estimated the mean mention order (MMO):

$$
M O M=\sum_{i=1}^{n} S t s / N
$$

Where Sts indicates the status of the species in the free listing, and $N$ is the total number of interviewees [35].

\section{Results}

\section{Non-edible mushrooms traditional knowledge}

\section{Non-edible mushrooms identified}

In total, we collected 178 specimens of mushroom considered non-edible by local community members. The specimens belong to 45 genera; two from the phylum Ascomycota and 43 from Basidiomycota. With 15 families, Agaricales was the best represented Order. The genera with the highest number of species were Amanita (12 spp), Cortinarius (9 spp), Russula (8 spp), Boletus and Clitocybe (5 spp) (Additional file 1).

We identified the taxonomic species of 120 specimens, which corresponded to 100 mushroom taxa. From these, 26 are reported in the literature as edible, 20 as non-edible and 10 as toxic; edibility is unknown for the remaining species (Additional file 1). Among the species reported as edible we found: Neoboletus erythropus (hongo-rado), Hygrophoropsis aurantiaca (brindis), Clavariadelphus truncatus (bate), and others (Additional file 1).

In both communities, 14 species were recognized as non-edible, and all non-edible mushrooms were considered poisonous. Species in such categories did not show a precise pattern with regards to their biological or ecological traits. An interesting finding was that, according locals, edible ethnotaxa could become poisonous when specimens are too ripened. This is the case for Amanita rubescens (poisonous cupcake/ mantecado de veneno) and Laccaria trichodermophora (poisonous xōlētl/xōlētl de veneno). Others could become poisonous when the foraging season is over, for example, Lyphyllum gpo. decastes (mushroom of the bush/hongo de mata/xolete).

\section{Discrimination attitudes}

During the ethnomycological expeditions, we observed different ways people approach non-edible mushrooms. There is a set of non-edible mushrooms that had proper names: citlal-nanacatl and hongo-rado, which can be recognized in plain sight, even from afar. These were handled with certain affinity, familiarity and even pleasure. Nonetheless, people intentionally destroyed them as a warning, to indicate that it is a poisonous mushroom and so, to prevent others from collecting it.

Another group of mushrooms did not have proper names (shrimp (camarón) and i-tlatla in cuā-te-cax). These were handled under particular circumstances like teaching, joking, curiosity, and identity confirmation. They were smelled, tasted, observed, and destroyed. The process of discrimination was executed in three stages: doubt, verification, and confirmation (Figure 2).

The third group had not proper names and was never handled. Although we asked about these species, they were met with a clear indifference, and therefore they are not destroyed (poisonous mushroom/hongo venenoso).

\section{Local nomenclature for mushrooms}

We obtained 179 local names (76 in FJM, 87 in SIBS and 16 shared) for non-edible mushrooms, 29 in Nahuatl, 97 in Spanish and 53 mixed. Traditional names corresponded to 130 genera, 47 taxonomic species and two of superior orders. Local names did not correspond with scientific names at a 1:1 ratio; in consequence, we grouped the local names into ethnotaxa, and identified the corresponding genus and species (Table 1). In general, mestizo Spanish speakers from FJM and Nahuatl speakers from SIBS designated the names of non-edible mushrooms by drawing comparisons with edible mushrooms. Spanish local names were composed of two words: noun and modifier, while Nahuatl names were formulated with a primary and a secondary lexeme.

The primary lexeme was formed by a root or nuclear modifier that generally matched the name of the similar edible mushroom, or "edible lookalike". The secondary lexeme or marginal modifier qualified the first and usually granted the non-edibility attribute. In SIBS particularly, the secondary lexeme was 
composed of the relational noun i-tlatla in that indicates kinship, and was followed by the term for the similar, edible counterpart. For example, i-tlatla in tlalpïltzal.

There was however a contrast in the nomenclature for the most culturally important non-edible mushrooms. These had a proper name that did not refer to an edible lookalike, even if one exists. Such is the case for Amanita muscaria $\nabla$ cittlal-nanacatl/ajonjolinado $\nabla$ and Neoboletus erythropus $\nabla$ hongo-rado $\nabla$ in

FJM. These proper names for non-edible species could contain modifiers that indicated specific traits that act as differentiators between varieties; for example, ajonjolinado blanco de encino, cittlal-nanacatl blanco de oyamel. Up to $40 \%$ of local names were mentioned by at least four people, and in general, these names were descriptive (cuerudo [leathery], volcancito [little volcano], ruleta [wheel], vidrioso [vitrous], etc.), references to elements of the environment such as animals (uña de ratón [mouse nail], venadito [little deer], pipilo), or references to characters (señoritas [ladies], oreja de diablo [devil's ear], etc.).

\section{Dual worldview}

People from both studied communities conceptualized non-edible mushrooms as being in conjunction with a similar edible mushroom, and this concept emanated from a perception of the duality between good (edible) and bad (poisonous). Local names were a clear example of such dual perception; in fact, people declared that to know an edible mushroom, it is necessary to know its poisonous counterpart to prevent mistakes that would put one's health at risk. In both communities, people thought that the bad is evident in the mushrooms' morphology: "Edible and poisonous mushrooms are very similar in plain sight, but if you know them well, you can see the difference between them".

Figure 3 shows the dual perception of non-edible mushrooms mentioned by more than $10 \%$ of people from both communities. For members of the FJM and SIBS community, the relationship between edible and non-edible mushrooms was very narrow and they even considered that one cannot exist without the other. This evidenced a complementarity that maintains the balance in the universe, where there cannot be more bad than good, since good controls bad and vice versa.

In FJM, they even compared the duality of good and bad mushrooms to the birth of twins; where according to their beliefs, one will get the good attributes while the other gets the bad ones. In SIBS, people used the noun i-tlatla in meaning "the lookalike" to refer to the good and bad duality.

\section{Identification criteria}

In total, interviewees mentioned 101 identification criteria for non-edible ethnotaxa, which were grouped as 32 general and 87 specific criteria. In both studied communities, there were 34 central criteria (abundance, unpleasant appearance, change of color after rough treatment, gills, fruitbody, color of the stipe and pileus, consistency, shape and thickness of the fruitbody, absence of worms, hymenium shape, pileus ornamentation, taste, and surface area). These were the most informative, detailed, and specific criteria, and sometimes they were included in the traditional names. Conversely, many specific criteria were used exclusively in one of the two communities; 24 in FJM (for example, big loculus, flat pileus and partial veil) and 43 in SIBS (shifting color with maturation, hymenium color, leathery cuticle, small stipe, pileus size and thickness, and fast decomposition).

These identification criteria are evidence that traditional methods for mushroom identification are based on the traits of fresh mushroom, where some attributes such as color, size, texture, thickness, weight, smell, taste, consistency and biotic environment, among others, are essential to differentiate edible from non-edible mushrooms. These criteria are related to the main characteristics that are used in classic taxonomy to distinguish organisms at a generic level; for example, scales on the pileus for the genus Amanita; color change after rough treatment for Boletales; branching patterns for coralloids; dentate hymenium for Sarcodon and Phellodon, and sporome color to discriminate varieties (Figure 4).

In both villages, we observed a consensus regarding the specific identification criteria for the most culturally important non-edible mushrooms (ajonjolinadocìtlal-nanacatl, pancita venenosa-popozoh-rrabia, panté de veneno-xo-tomāh de veneno, escobeta de veneno-xelhuāz de veneno, corneta de veneno-tlalpīltzal de veneno). Meanwhile, for ethnotaxa of lesser importance, the less relevant there were, the less precise were the criteria, and there was no consensus.

\section{Classification systems}

In both communities, we identified a classification system that is based on anthropocentric utility. It established a general group, mushrooms/hongos/nanacatl, which was subdivided in two subgroups: 1) edible mushrooms/hongos comestibles/cualinanacatl (encompassing all mushrooms that are part of their diets), and 2) poisonous mushrooms/hongos venenosos/ pitzō-nanacatl (encompassing all mushrooms of null or unknown edibility). However, the lexical aspects of local names as well as the identification criteria both refered to traits that can be classified into more complex subdivisions (Figure 5). This classification proposal corresponded to a hierarchical inclusion scheme that is based on the structural criteria for morphological identification (shape, color, habitat, substrate, smell, taste, consistency), to distinguish non-edible species from edible species.

\section{Uses}

In both sites, most people (55.5\% in FJM and $66.6 \%$ in SIBS) stated that non-edible mushrooms are useless. However, an important proportion of the population mentioned different anthropocentric categories, such as medicine (18.5\% in FJM and $11.1 \%$ in SIBS), drug (3.8\% in FJM and $3.7 \%$ in SIBS) and insecticide (3.8\% in FJM and $11.1 \%$ in SIBS). The use as insecticide was the most common in SIBS, and it was attributed to $A$. muscaria, which was also recognized as a medicine when consumed in small amounts to induce vomiting (current use) or to control tachycardia (discontinued use). This species was also reported as edible, provided the scales and cuticle are removed. Medicinal and culinary uses of $A$. muscaria have disappeared, since they were formerly performed by elders.

In FJM, 25.6\% of interviewees mentioned that Neoboletus erythropus (hongo-rado) is traded in the main markets of Puebla and Mexico City. This commercialization is recent, and the mushroom pickers/hongueros had to assimilate the idea that this mushroom is being used as a medicine in both cities 
before they agreed to sell a specimen considered poisonous. Currently, there are families that specialize in collecting this species, and they obtain significant economic benefits by collecting several kilograms a day. Nonetheless, medicinal use has not yet been integrated into traditional practices in FJM, since they still consider it as a poisonous mushroom with commercial use.

\section{Symptoms and local remedies used to treat mycetism}

Most members of both communities associated the consumption of non-edible mushrooms with death (49\% in FJM and 59\% in SIBS). However, they acknowledged that some of them only cause specific intoxications (38\% FJM and 30\% SIBS), hallucinations ( $3 \%$ FJM) and even cancer (1\% FJM and SIBS). Interviewees posed that all intoxications are not the same, but that every mushroom possesses a type of poison, and consequently, that the symptoms are specific, ranging from gastrointestinal problems to death (Figure 6).

In the two communities, a significant proportion of the interviewees indicated that there aren't any existing local remedies for intoxications caused by wild mushroom consumption ( $20 \%$ in FJM and $49.2 \%$ in SIBS). They considered that the only option is to consult a physician to get medication. Nevertheless, $32 \%$ of the people interviewed in FJM and $31.6 \%$ in SIBS denoted the availability of local remedies to mitigate the discomfort caused by intoxications and even to avoid death.

Traditional remedies aimed to mitigate the symptoms caused by mushroom intoxication; for example, the treatment for gastrointestinal problems is the ingestion of garlic tea, vinegar and milk, to purge the organism of the ingested mushroom, and as such, eliminate the effects of the intoxication. This remedy is followed by an infusion of peppermint, chamomile and skunk epazote to help to restore the stomach. Interestingly, SIBS habitants mentioned that ingestion of alcoholic beverages like pulque (fermented sap of some Agave species) and aguardiente (cane liquor) is one of the most effective cures to avoid death by mushroom poisoning

In both sites, this knowledge of mushrooms was distributed within the adult population and was gender related: The women are the ones who go to the forest to forage resources and medicinal plants, while the men who devote their days to agriculture show a more detailed knowledge of the remedies and their effects against the symptoms of intoxication.

\section{Cultural importance}

Cultural importance indicators showed that the most important ethnotaxa for both communities were Amanita muscaria (ajonjolinado-cittlal-nanacatt), Neoboletus erythropus-Xerocomellus chrysenteron (hongo-rado-panté, venenoso-xo-tomāh rabia) and Suillus pseudobrevipes/S. tomentosus (popozoh venenoso, de veneno). When comparing the taxa presented in both villages, in FJM, N. erythropus (hongo-rado) was a different ethnotaxa than the rest of Boletales species; while in SIBS, this species was considered part of this group. For statistical analysis, $N$. erythropus was placed into Boletales (Table 2).

In FJM the most important taxa were A. muscaria (ajonjolinado de veneno), Pholiota sp. 1/Psathyrella sp. 1 (xolete de veneno) and N. erythropus (hongorado). The most frequently mentioned was $A$. muscaria (ajonjolinado de veneno) with a clear difference between this species and the remaining ones (Additional file 2). In SIBS, Boletales (xo-tomāh de veneno), A. muscaria (cittlal-nanacat) and Sarcodon spp./ Phellodon spp. (tlalpīltzal de veneno) were the most commonly cited. Although the FM of Boletales was the highest, $A$. muscaria (citlal-nanacat) was more often mentioned first, explaining its higher ordinal value of rank (Additional file 3). Also, there was no consensus between both communities regarding the status of the two most important taxa ( $A$. muscaria in FJM, and B. aff. bicolor, N. erythropus and Xerocomellus chrysenteron in SIBS).

\section{Discussion}

Our results revealed that the traditional knowledge of non-edible mushrooms is vast and profound, evidencing their role in the people's worldview. We described the characteristics used to identify toxic mushrooms and discriminate their utility. In such sense, we propose that the use of wild mushrooms is not a central axis to build knowledge around them. According to Berlin [8], knowledge is built from the identification of attributes that play a role in the culture, and conforming to Lévi-Strauss' structuralism [6], comprehension comes first - before a utility is assigned.

\section{Traditional knowledge of non-edible mushrooms}

The use of wild mushrooms is possible thanks to the lore accumulated in people cultural memory, based on their worldview. Such cultural heritage improves through the recognition of distinctive characteristics that let people differentiate non-edible mushrooms from edible ones. Conceptual representations are built from group and individual experiences that become rational collective knowledge and remain in the collective unconscious [74].

Our data showed that non-edible fungi species are key factors in the kosmos, corpus, and praxis of traditional knowledge of wild mushrooms [5]. We identified more than 100 non-edible taxa; in contrast, other ethnomycological studies usually mention up to 17 species that are recognized as toxic or poisonous $[13,41]$. Moreover, the characterization of local knowledge on non-edible mushrooms has been superficial and is generally the result generalizations from edible mushrooms $[11,16,19,75]$.

It's interesting that in this study, among the species recognized as non-edible, some have previously been reported as edible [26], such as Amanita rubescens and Laccaria trichodermophora, who were considered toxic when very ripe. This concurs with studies on the Karbi people of Northeastern India, that found that some species lose their taste when ripened, and are therefore collected and consumed only at their juvenile stage [17]. This phenomenon has also been recorded in Southern Mexico, where the Tseltales report some edible species as toxic [13]. Similarly, the consumption of species known as toxic, such as Tricholoma equestre, has been documented [76]. In the present study, in both localities, the local names blanco venenoso and iztāc nanacatl de veneno refered 
to white species of the genus Amanita that have already caused intoxications in the region [26]. However, we did not find their fruitbodies to make a proper taxonomic identification.

The fact that people considered as poisonous all mushrooms that they do not include in their diet indicates that knowledge and interest depends on traditions of consumption $[15,17,19,30,40,41]$. There are only a few cases where a species that has not been used within the family nucleus has been integrated in the diet, showing a degree of rejection of the unknown, due to intoxication risks [77]. In contrast, mushrooms pickers and traders were more willing to learn about species that are not part of their lore. In Figure 7, we show a graphic contrast of the non-edible mushrooms concepts using the emic versus etic approaches, evidencing that the general category "poisonous mushrooms" can only be explained from an etic perspective [78].

The way people discriminated non-edible mushrooms during the collection process is a practical depiction of their knowledge; those more similar to edible species are more important and appreciated. General identification criteria matched with those reported in ethnomycological research conducted in temperate zones in Mexico [16]. This sustains the findings by Estrada-Torres and Aroche [79], Montoya et al. [26] and Moreno-Fuentes [80]: Inhabitants of temperate zones possess exhaustive knowledge to differentiate toxic species from edible ones, and they even learned to recognize traits and establish traditional criteria for mushrooms recognition. Such precision in discriminating species has also been reported for the Kurya tribe and the Kabi culture, who use traditional indicators associated to specific characteristics of the mushrooms that grow in their territory; for example, smell, color, size, habitat and substrate where they grow $[17,75]$. Conversely, cultures from The Northwestern Andes in Colombia use strong and vivid colors, spicy or bitter taste as hazard indicators [40]. Some of the criteria used by cultures resemble those used in classic mycology [17].

\section{Nomenclature and discrimination of non-edible mushrooms}

Local names are a collective mental construct, where each ethnotaxon is delimited by perceptible characteristics surrounded by the particular wisdom of every culture[74]. The 181 local names referring to non-edible mushrooms obtained in our study showed the wealth of knowledge that exists on the subject; this number represents $60 \%$ of all traditional names of non-edible mushrooms currently recognized in Latin America [81]. On a regional scale, our findings represent more than 10 times the number of local names previously reported in the area $[26,48]$. Despite the vast diversity of local names, only 13 in FJM and 15 in SIBS were mentioned by more than $10 \%$ of the interviewed participants. An important amount of local names (40.2\%) were idiosyncratic [3].

Studies conducted in different parts of the world report that non-edible mushrooms are identified in general terms, without specific names, and only classified as non-edible $[13-15,20,41]$. Scarce studies report one or two local names to refer to non-edible ethnotaxa $[2,11,26,30,32]$. The names emerge by contrasting non-edible with edible mushrooms, and each ethnotaxon is delimited by certain types of characteristics that allow for its recognition. In this nomenclatural scheme we observed that only the most remarkable species, or the ones that represent health hazards, have a name, but as their relevance declines, so does the interest to assign them names $[9,11,13,30,41]$. In addition, the names demonstrate the pragmatic character of the nomenclature, where a vast knowledge of morphologic, ecologic, phenologic and qualitative traits is employed to allow the recognition of every ethnotaxon [8].

\section{Dual worldview}

Traditional mycological knowledge is developed and acquired in an integral manner. Learners cannot limit themselves to useful mushrooms, they also need specific information to be able to differentiate them from toxic lookalikes [42]. This reflects a close relation between edible and non-edible mushrooms, and shows their dual nature. The "double edible" approach has been reported in diverse ethnomycological studies, which stipulate that names of non-edible mushrooms contain terms that indicate the opposition to an edible variety, e.g.: the bad [...], partner, older brother, friend [13,30]. Haro-Luna [19] documented the dual worldview of the Wixarika people regarding edible $v s$ toxic mushrooms: the first pertain to tangible reality, while the second pertain to the spiritual realm and must not be eaten. Dual perception of mushrooms is not restricted to edible/non-edible organisms; for example, the Mixes and the Mazatecos point out that one of the rules to consume sacred mushrooms is to ingest them in pairs, symbolizing the balance of the universe and the duality of woman and man $[82,83]$.

\section{Classification of non-edible mushrooms}

Mushroom categorization is based on assigned use [20]. Identification criteria have a hierarchical structure that is based on observable specific traits [8,9,11], where utilization is signified in the second term, indicating that people classify and use resources at the same time [84,85]. Categories are constructed from judgments of similarity or hierarchical resemblance networks, linguistically represented by descriptive terms that aim to represent nature in an orderly manner [11].

\section{Poisonous mushrooms with others uses}

Different uses for non-edible mushrooms have been recorded in the region of La Malintzi National Park $[26,48,86]$. The use of $A$. muscaria as an insecticide is a highly documented aspect, in fact, many of its local names refer to its link with flies [15,87]. Its medicinal use has also been recorded in different communities of Mexico and the world $[14,15,87]$. It is closely related to its use in rituals, considering the species as a sacred element in diverse cultures, mainly in Europe and Asia [87]. Edibility of this species is frequently cited in some communities from temperate zones [15,87].

In the case of $N$. erythropus (hongo-rado) and its use as medicine, it is a recent knowledge derived from commercial interests [26]. Association of non-edible mushrooms to neurotropics (emborrachantes or locos) is a generalized perception, perhaps because they have sacred uses in diverse cultures around the world, and such uses are related to psychoactive properties $[15,16,30]$.

\section{Symptoms and local remedies to treat mycetism}


Members of both studied communities associated the consumption of poisonous mushrooms with death; however, they also admited that some species only cause discomfort or intoxication. Some studies suggest that the recognition of symptoms is a part of traditional mycological knowledge, specifically, the detection of diverse types of mycetism [16]. However, there are some exceptions. For instance, Mayan people from Chiapas describe a general pattern: The first stage is a psychoactive intoxication, followed by gastrointestinal disorders, tissue and organ damage, and finally, death [30]. Our results are in opposition to this particular belief, since people participating in our study claimed that not all types of mushroom intoxications are equal, because each mushroom has its own poison. Consequently, the symptoms provoked are specific and not all are deathly.

In fact, there are several types of local remedies, which evidence the richness of local knowledge about non-edible mushrooms. For instance, in Northeast India, the Karbis use 12 different traditional cures for mycetisms, e.g. corn, citric, rice, tamarind, soil and human feces, among others [17]. Various studies in Central and Southern Mexico have reported the most prevalent traditional remedies are those with laxative effects, such as salted water, crushed garlic, cooking oil, lemon juice or mezcal [16]. This shows some degree of convergence in local knowledge from different regions.

\section{Non-edible mushrooms cultural importance}

We observed that, traditional knowledge about non-edible mushrooms is sparse, and only its most relevant elements are distributed throughout most of the community. However, knowledge about them is evidence that some indicators can be used to evaluate the role of this elements in a culture [88]. In general, the cultural importance of non-edible mushrooms resulted from the knowledge of the entire range of species, which led to different uses (Figure 8), and although non-edible mushrooms do not have explicit uses, they play relevant roles in cultures [41].

The most important non-edible mushrooms of both communities were those that tend to relate to the most meaningful edible mushrooms. The same trend was reported for two Mayan groups in Chiapas, Mexico: the Tsotsiles and the Tseltales [13,41]. The relevance is determined by the role of the double edible, according to specific categories: 1) those present in people's worldview through a dual scheme (good/bad), and in their stories (myths, legends and tales); 2 ) those related to an edible duality but with their own identity, which separates them from the rest in a nomenclatural form; 3 ) those with a set of clear and precise traits that group them in specific ethnotaxon, and that have consensus names; 4 ) those whose consumption has very well-known symptoms and consequences, 5) those known to be toxic, but used anyway; 6) the most abundant in the forest; and 7) the most frequently mentioned in free listings.

\section{Conclusions}

Local knowledge about non-edible mushrooms is a fundamental part of traditional mycological knowledge. In Mesoamerica, such comprehension is constructed in a dual principle, essential for discriminating potentially dangerous mushrooms. Non-edible mushrooms form a very large and heterogeneous group, which is defined by comparison with edible mushrooms; in other words, all that is non-edible is poison. Preferences for certain species result from sociocultural factors as well as from beliefs that emerge and are transmitted through myths, legends and taboos, which are specific to every community and culture.

Previously, resources without use were considered as not important for cultures, and therefore, were neither studied nor named. However, our study documented a huge amount of local knowledge regarding non-edible mushrooms or mushrooms that are not used. Such knowledge: is scattered; rarely leads to consensus or lexical retention; is narrowly related to edible mushrooms; and is essential to avoid mycetism and death. Local knowledge of non-edible mushrooms depends on the status of each mushroom in the cultural domain, which is homogeneous, precise, profound and with consensus for the most important species. But as the relevance of the species diminishes, knowledge about them becomes heterogeneous, very general, disperse and lacking consensus.

Documentation, diffusion and enhancement of traditional knowledge about non-edible mushrooms represent an encouraging strategy to prevent intoxications. To guarantee that wild mushrooms consumption is practiced in a safe manner, it is necessary to apply local knowledge during foraging and preparation activities, and in the administration of primary care to counter intoxications.

\section{Abbreviations}

FJM: Francisco Javier Mina; SIBS: San Isidro Buensuceso; PNLM: La Malintzi National Park; MF: Mention frequency; MO: Mention order; ROV: Rank ordinal value; MMO: Mention mean order.

\section{Declarations}

\section{Ethics approval and consent to participate}

The authors declare that participant communities were efficiently informed about the methods implemented and goals of this study. Each person who collaborated answering the questions during interviews, during field trips and sharing fungi activities in town, were informed about the goal of the research. The were agree to participate. The authors follow the suggestions listed on two Codes of Ethics (International Society of Ethnobiology 2006 http://ethnobiologynet/codeofethics/; http://asociaciónetnobiologica.org.mx/aem/codigo-de-etica-de-solae 2015). During the course of the research two talks (about mushroom significance and medicinal mushrooms) were shared with ladies of San Isidro Buensuceso in the local health Clinic. Different personal projects research are in progress too, actually for our team.

\section{Consent for publication}

Not applicable. 


\section{Availability of data and materials}

Data sharing Not applicable to this article as no data sets were generated or analysed during the current study.

\section{Competing interests}

The authors declare that they have no competing interests..

\section{Funding}

The first author had financing support for postgraduate studies from Consejo Nacional de Ciencia y Tecnología (CONACyT-Mexico). Scholarship: 3850746.

\section{Acknowledgements}

ART thanks the Programa de Posgrado en Ciencias Biológicas, Universidad Nacional Autónoma de México and CONACYT for PhD financial support (CVU: 3850746). The authors aknowledge all people contributing to the development of this Project, mainly to members of the studied communities in Tlaxcala: María Alejandra Romero, Lorenza Pérez Flores, Pánfilo Domínguez Manzano, Francisco Rojas Pérez, Domingo Domínguez and María Isabel Pérez. Thanks to Grupo Interdisciplinario para el Desarrollo de la Etnomicología en Mesoamérica A.C. (GIDEM) for the support and encouragement. Thanks to Daniel Pérez Rendón for the elaboration of the figures. Thanks to Jean-François Melançon for correcting the English version of this manuscript. Dedicated to the memory of Dr. Javier Caballero Nieto for his support and knowledge for the development of this project.

\section{Authors' contributions}

ART designed the study, conducted field work, identified the specimens, analyzed data and wrote the manuscript. AM reviewed and edited the study design and the manuscript, and collaborated in data analysis. RGO collaborated in the study design and reviewed the manuscript. JC reviewed and edited the study design and the manuscript. AKL identified the specimens. CME reviewed and edited the manuscript. All authors read and approved the final version of the manuscript.

\section{References}

1. Ford RI. History of Ethnobiology. In: E. Anderson, Deborah Pearsall, Eugene Hunn NT, editor. Ethnobiology. United States of America: Wiley-Blackwell. 2011; p. 420.

2. Agnihotri S, Si A. Solega Ethno-Ornithology. 2012; 32:185-211. (https://doi.org/10.2993/0278-0771-32.2.185)

3. Zamudio F, Hilgert NI. Multi-dimensionality and variability in folk classification of stingless bees (Apidae: Meliponini). J Ethnobiol Ethnomed, 2015; 11(1), 41. (http://dx.doi.org/10.1186/s13002-015-0029-z)

4. Zent SZ, Zent E. Co-ecology of Jotï, Primates, and Other People: A Multispecies Ethnography in the Venezuelan Guayana. In: Urbani B, Lizarralde M, editors. Neotrop Ethnoprimatology Indig peoples' perceptions of and interactions with nonhuman primates. 2020. p. 416. (https://doi.org/10.1007/978-3030-27504-4)

5. Toledo VM. Indigenous Peoples and Biodiversity. Encycl Biodivers. 2001. p. 452-63. (https://doi.org/10.1016/B978-0-12-384719-5.00299-9)

6. Lévi-Strauss C. Mitológicas I: Lo crudo y lo cocido. México: Fondo de Cultura Económica;1968.

7. Berlin B, Breedlove DE, Raven H.P. General Principles of Classification and Nomenclature in Folk Biology. Am Anthropol. 1973; 75:214-41. (https://doi.org/10.1525/aa.1973.75.1.02a00140)

8. Berlin B. Ethnobiological Classification: Principles of Categorization of Plants and Animals in Traditional Societies. NEW JERSEY: Princeton University Press; 1992. (https://doi.org/10.1525/ae.1994.21.2.02a00220)

9. Hunn E. The Utilitarian Factor in Folk Biological Classification. Am Anthropol. 1982; 84:830-47. (https://doi.org/10.1525/aa.1982.84.4.02a00070)

10. Lampman AM. General Principles of Ethnomycological Clasification Among Tseltales in Tenejapa Chiapas. J Ethnobiol. 2007; 27:11-27. (https://doi.org/10.2993/0278-0771(2007)27[11:GPOECA]2.0.CO;2)

11. Ellen R. Ethnomycology among the Nuaulu of the Moluccas: Putting Berlin's "general principles" of ethnobiological classification to the test. Econ Bot. 2008; 62:483-96. (https:// DOI: 10.1007/s12231-008-9036-5)

12. Zent E, Zent S. Ebojto: Plantas Trepadoras entre los jotï, Guayana Venezolana. Etnobiología. 2016;14:5-38. (https://cutt.ly/GgjLSnp)

13. Ruan-Soto F. Highly cultural significant edible and toxic mushrooms among the Tseltal from the Highlands of Chiapas, Mexico. Ethnobiol Conserv. 2020;32. (https://ethnobioconservation.com/index.php/ebc/article/view/414)

14. Boa E. Los hongos silvestres comestibles: Perspectiva global de su uso e importancia para la población. Prod. For. no madereros. Roma, Italia: FAO; 2005. (https://www.researchgate.net/publication/44720490_Los_hongos_silvestres_comestibles_perspectiva_global_de_su_uso_e_importancia_para_la_poblaci

15. Yamin-Pasternak S. Ethnomycology: Fungi and Mushrooms in Cultural Entanglements. In: E. Anderson, Deborah Pearsall, Eugene Hunn NT, editor. Ethnobiology. Hoboken, New Jersey: John Wiley \& Sons, Inc.; 2011. p. 420. (https://doi.org/10.1002/9781118015872.ch13)

16. Ramírez-Terrazo A, Montoya A, Caballero J. Una mirada al conocimiento tradicional sobre los hongos tóxicos en México. In: Moreno-Fuentes A, GaribayOrijel R, editors. La etnomicología en México, estado del arte. 1ra ed. Mexico City: Red de Etnoecología y Patrimonio Biocultural (CONACyT)-Universidad Autónoma de Hidalgo-Instituto de Biología (UNAM)-Sociedad Mexicana de Micología-Asociación Etnobiológica Mexicana, A. C.-Grupo Interdisciplinario para el Desarrollo de la Etnomicología en; 2014. p. 116-45. (https://scholar.google.es/scholar?hl=es\&as_sdt=0,5\&cluster=4526596717230559013) 
17. Prila y Teron RH. Eschewing poisons: An ingenious wisdom of foraging macrofungi by Karbi ethnic group in North East India. Curr Sci. 2018;115:132833. (https://www.researchgate.net/figure/Map-of-Karbi-Anglong-district-Assam-North-East-India_fig1_328163140)

18. Ruan-Soto F. Intoxicaciones por consumo de hongos silvestres entre los tsotsiles de Chamula, Chiapas, México. Soc y Ambient. $2018 ; 7$. (scielo.org.mx/scielo.php?script=sci_arttext\&pid=S2007-65762018000200007)

19. Haro-Luna MX, Ruan-Soto F, Guzmán-Dávalos L. Traditional knowledge, uses, and perceptions of mushrooms among the Wixaritari and mestizos of Villa Guerrero, Jalisco, Mexico. IMA Fungus. IMA Fungus; 2019;10:1-14. (https://link.springer.com/article/10.1186/s43008-019-0014-6)

20. Reyes-López RC, Montoya A, Kong A, Cruz-Campuzano EA, Caballero-Nieto J. Folk classification of wild mushrooms from San Isidro Buensuceso, Tlaxcala, Central Mexico. J Ethnobiol Ethnomed. Journal of Ethnobiology and Ethnomedicine; 2020;16:53. (D0I: 10.1186/s13002-020-00408-x)

21. Cano-Estrada A, Romero-Bautista L. Valor económico, nutricional y medicinal de hongos comestibles silvestres Economic , nutritional and medicinal value of edible wild mushrooms. Rev Chil Nutr. 2016;43:75-80. (http://dx.doi.org/10.4067/S0717-75182016000100011)

22. Arora D. California porcini: Three new taxa, observations on their harvest, and the tragedy of no commons. Econ. Bot. 2008 . p. 356-75. (https://link.springer.com/article/10.1007\%2Fs12231-008-9050-7)

23. Trutmann P, Unsaac MEH, Unsaac AQ, Luque A. Native Mushrooms, Local Knowledge, and Potential for Food and Health in the Peruvian Andes: Update 2012. 2012.

(https://www.researchgate.net/publication/261984725_Native_Mushrooms_Local_Knowledge_and_Potential_for_Food_and_Health_in_the_Peruvian_Ande

24. Pérez-Moreno J, Martínez-Reyes M, Yescas-Pérez A, Delgado-Alvarado A, Xoconostle-Cázares B. Wild mushroom markets in central Mexico and a case study at Ozumba. Econ Bot. 2008;62:425-36. (DOI: 10.1007/s12231-008-9043-6)

25. Guzmán G. El Uso Tradicional de los Hongos Sagrados: Pasado y Presente. Etnobiología. 2011;9:1-21. (https://revistaetnobiologia.mx/index.php/etno/article/view/257)

26. Montoya A, Hernández-Totomoch 0 , Estrada-Torres A, Kong A, Caballero J. Traditional knowledge about mushrooms in a Nahua community in the state of Tlaxcala, México. Mycologia. 2003; 95:793-806. (https://cutt.ly/lgjZNM8)

27. Ruan-Soto F, Mariaca R, Alvarado R. Intoxicaciones mortales por consumo de hongos: una cadena de errores. Eco Front Rev cuatrimestralde Divulg la Cienc; 2011. Pág. 12-14. (https://revistas.ecosur.mx/ecofronteras/index.php/eco/article/view/741)

28. Shepard G. The forgotten kingdom: Mush- rooms and ethnobiology. Pap Present Am Anthropol Assoc Meet. Atlanta; 1997;16 pp.

29. Shepard GH, Arora D, Lampman A. The grace of the flood: Classification and use of wild mushrooms among the highland Maya of Chiapas. Econ Bot. 2008;62:437-70. (https://link.springer.com/article/10.1007/s12231-008-9044-5)

30. Zent EL, Zent S, Iturriaga T. Knowledge and use of fungi by a mycophilic society of the Venezuelan Amazon. Econ Bot. 2004;58:214-26. (https://link.springer.com/article/10.1663/0013-0001(2004)058[0214:KAUOFB]2.0.C0;2)

31. Teke NA, Kinge TR, Bechem E, Nji TM, Ndam LM, Mih AM. Ethnomycological study in the Kilum-ljim mountain forest, Northwest Region, Cameroon. J Ethnobiol Ethnomed. Journal of Ethnobiology and Ethnomedicine. 2018;14:1-12. (DOI: 10.1186/s13002-018-0225-8)

32. Ruan-Soto F. Recolección de hongos comestibles silvestres y estrategias para el reconocimiento de especies tóxicas entre los tsotsiles de Chamula, Chiapas, México. Sci Fungorum. 2018;48:1-13. (https://doi.org/10.33885/sf.2018.48.1179)

33. Montoya A, Kong A, Torres-García E. Síntesis de los métodos cuantitativos empleados en Etnomicología. In: Moreno-Fuentes A, Garibay-Orijel R, editors. La Etnomicología en México Estado del Arte. Red de Etnoecología y Patrimonio Biocultural (CONACyT)-Universidad Autónoma de Hidalgo-Instituto de Biología (UNAM)-Sociedad Mexicana de Micología-Asociación Etnobiológica Mexicana, A. C.-Grupo Interdisciplinario para el Desarrollo de la Etnomicolog; 2014. p. 221-41.

34. Burrola-Aguilar C, Montiel O, Garibay-Orijel R, Ziumbo-Villarreal L. Conocimiento tradicional y aprovechamiento de los hongos comestibles silvestres en la región de Amanalco, Estado de México. Rev Mex Micol. 2012;35:1-16. (http://www.scielo.org.mx/scielo.php?script=sci_arttext\&pid=S018731802012000100002)

35. Montoya A, Torres-García EA, Kong A, Estrada-Torres A, Caballero J. Gender differences and regionalization of the cultural significance of wild mushrooms around la Malinche Volcano, Tlaxcala, Mexico. Mycologia. 2012;104:826-34. (DOI: 10.3852/11-347)

36. Garibay-Orijel R, Caballero J, Estrada-Torres A, Cifuentes J. Understanding cultural significance, the edible mushrooms case. J Ethnobiol Ethnomed. 2007;3:1-18. (DOI: 10.1186/1746-4269-3-4)

37. Bautista-Nava E, Moreno-Fuentes A, Pulido-Silva MT, Valadez Azúa R. Bases bioculturales para el aprovechamiento y conservación de los hongos silvestres comestibles en el Municipio de Tenango de Doria, Hidalgo, México. In: Moreno-Fuentes A, Pulido-Silva T, Mariaca-Méndez R, Valadéz-Azúa R, Mejía-Correa P, Gutiérrez-Santillán TV, editors. Sist Biocognitivos Tradic Paradig en la Conserv Biológica y el Fortalec Cult. Asociación Etnobiológica Mexicana, A.C., Global Diversity Fundation, Universidad Autónoma del Estado de Hidalgo, El Colegio de la Frontera Sur, Sociedad Latinoaméricana de Etnobiología. 2010. p. 226-31. (https://repository.uaeh.edu.mx/bitstream/handle/123456789/7595)

38. Alonso-Aguilar LE, Montoya A, Kong A, Estrada-Torres A, Garibay-Orijel R. The cultural significance of wild mushrooms in San Mateo Huexoyucan, Tlaxcala, Mexico. J Ethnobiol Ethnomed. 2014;10:1-14. (DOI: 10.1186/1746-4269-10-27)

39. Robles-García D, Suzán-Azpiri H, Montoya-Esquivel A, García-Jiménez J, Esquivel-Naranjo EU, Yahia E, et al. Ethnomycological knowledge in three communities in Amealco, Quéretaro, México. J Ethnobiol Ethnomed. Journal of Ethnobiology and Ethnomedicine. 2018;14:1-13. (DOI: 10.1186/s13002017-0202-7)

40. Peña-Cañon ER, Enao-Mejía LG. Conocimiento y uso tradicional de hongos silvestres de las comunidades campesinas asociadas a bosques de roble (Quercus humboldtii) en la zona de influencia de la Laguna de Fúquene, Andes Nororientales. Etnobiologia. 2014;12:13.

(https://revistaetnobiologia.mx/index.php/etno/article/view/169)

Page $10 / 19$ 
41. Ruan-Soto F. Sociodemographic differences in the cultural significance of edible and toxic mushrooms among Tsotsil towns in the Highlands of Chiapas, Mexico. J Ethnobiol Ethnomed. 2018;14:1-19. (doi: 10.1186/s13002-018-0232-9)

42. Ammirati, J.F., Traquair, J.A., Horgen PA. Poisonous Mushrooms of the Northern United States and Canada. Minneapolis: University of Minnesota Press; 1985.

43. Pacheco-Cobos L, Rosetti M, Hudson R. A new method for tracking Pathways of humans searching for wild, edible fungi. Micol Apl Int. $2009 ; 21: 77-87$. (https://www.redalyc.org/articulo.oa?id=68511349001)

44. Pacheco-Cobos L, Rosetti M, Cuatianquiz C, Hudson R. Sex differences in mushroom gathering: Men expend more energy to obtain equivalent benefits. Evol Hum Behav. Elsevier B.V. 2010;31:289-97. (http://dx.doi.org/10.1016/j.evolhumbehav.2009.12.008)

45. López-Domínguez J, Acosta-Pérez R. Descripción del Parque Nacional Malinche. Primera Ed. Fernández JA, López JC, editors. Biodivers. del Parq. Nac. Malinche. Tlaxcala, México: Coordinación General de Ecología, Gobierno del Estado de Tlaxcala. México.; 2005.

(https://www.academia.edu/12611845/Biodiversidad_del_Parque_Nacional_Malinche)

46. Montoya Adriana, Méndez-Espinoza Claudia, Flores-Rivera Rodrigo, Kong Alejandro E-TA. Hongos tóxicos de Tlaxcala libro.pdf. Nieto de Pascual Pola Cecilia, Camacho Morfín Francisco H-TT, editor. Instituto Nacional de Investigaciones Forestales Agrícolas y Pecuarias, Universidad Autónoma de Tlaxcala; 2007. (https://scholar.google.es/scholar?hl=es\&as_sdt=0,5\&cluster=7918832703906215707)

47. INEGI. Censo General de Población y Vivienda Principales resultados por localidad. México; 2010. (https://www.inegi.org.mx/programas/ccpv/2010/)

48. Montoya Esquivel A. Aprovechamiento de los hongos silvestres comestibles en el volcán de La Malinche, Tlaxcala. $2005 ; 159$. (http://132.248.9.195/ptd2005/00387/0345191/Index.html)

49. Romero-Contreras T. Los temazcales de San Isidro Buen Suceso. Gobierno del Estado de Tlaxcala. México; 1998.

50. Nava NR. Las ideologías lingüísticas a favor del náhuatl en San Isidro Buensuceso, Tlaxcala. Tlaxcala, México: Universidad Atónoma de Tlaxcala, Facultad de Filosofía y Letras.; 2012. (https://doi.org/10.5209/REAA.58286)

51. Cano-Contreras EJ, Medinaceli A, Sanabria OL, Argueta A. Código de Ética para la investigación, la investigación-acción y la colaboración etnocientífica en América Latina. Etnobiología. 2016;14(Suppl 1). (https://cutt.ly/cgjXWwk)

52. Rodríguez-Gómez G, Gil-Flores J, García-Jiménez E. Metodología de la investigación cualitativa; 1999. p. 105.

(http://catedranaranja.com.ar/taller5/notas_T5/metodologia_investig_cap.3.pdf)

53. Fine GA. Towards a Peopled Ethnography: Developing theory from group life. Ethnography. 2003;4(1):41-60. (https://doi.org/10.1177/1466138103004001003)

54. Cifuentes J, Villegas M, Pérez-Ramírez L. Hongos. In: Lot A, Chiang F, editors. Manual de Herbario: Administración y manejo de colección; 1986. p. 55-64.

55. Lodge DJ, Ammirati JF, O’Dell TE, Mueller GM. Collecting and describing macrofungi. Biodivers fungi Invent Monit methods; 2004. p. 128-58.

56. Romagnesi H. Les Russules d’Europe et dÁfrique du Nord. París: Bordas; 1968. (https://scholar.google.es/scholar? $\mathrm{hl}=$ es\&as_sdt=0\%2C5\&q=Romagnesi+H.+Les+Russules+d+\%CC\%81Europe+et+de+\%C3\%81frica+du+Nord.+Pari\%CC\%81s\%3A+Bordas\%3B+1967.+\&btnG

57. Corner EJH. Supplement to a Monograph of Clavaria and Allied Genera. J. Cramer. Lehre.; 1970. (DOI: 10.2307/1218546)

58. Petersen RH. Ramaria subgenus Lentoramaria with emphasis on North American Taxa. Bible. Mycol. 1975;43,1-161. (https://scholar.google.com/scholar? $\mathrm{hl}=$ es\&as_sdt=0\%2C5\&q=Petersen+RH.+Ramaria+subgenus+Lentoramaria+with+emphasis+on+North+Amerivan+Taxa.+Biblth.+Mycol.+1975.+\&btnG=59

59. Moser M, Kibby G. Keys to Agarics and Boleti: Polyporales, Boletales, Agaricales, Russulales. London: Roger Phillips; 1983. (https://scholar.google.es/scholar?

hl=es\&as_sdt=0\%2C5\&q=Moser+M.+Keys+to+Agarics+and+Boleti+\%28Polyporales\%2C+Boletales\%2C+Agaricales\%2C+Russulales\%29.+London\%3A+Ro

60. Estrada-Torres A. La familia gomphaceae (Aphyllophorales, fungi) en el estado de Tlaxcala. Tesis de Doctorado, Escuela Nacional de Ciencias Biológicas, Instituto Politécnico Nacional; 1994. 186 p. (https://scholar.google.es/scholar?hl=es\&as_sdt=0\%2C5\&q=Estrada-

Torres+A.+La+familia+gomphaceae+\%28Aphyllophorales\%2C+fungi\%29+en+el+estado+de+Tlaxcala.+Instituto+Polite\%CC\%81 cnico+Nacional.\%3B+199

61. Tulloss RE. Seminario sobre Amanita. Universidad Autónoma de Tlaxcala, Tlaxcala. México.; 1994.

62. Kong A. Estudio taxonómico sobre el género Lactarius (Russulales, Mycetae) en el Volcan La Malintzi, Tlaxcala. Universidad Nacional Autónoma de Mexico. 1995. p 158. (http://oreon.dgbiblio.unam.mx/F/K6DCDYHYAGPSICY6YNPUPGJU51TXK92KSIAUV1UXGFUEVD873A-57417?func=full-setset\&set_number=022793\&set_entry=000002\&format=999)

63. Kong A. El género Russula (Fungi, Russulales) en el Parque Nacional La Malinche. Universidad Nacional Autónoma de México. 2003. P 192. (http://oreon.dgbiblio.unam.mx/F/K6DCDYHYAGPSICY6YNPUPGJU51TXK92KSIAUV1UXGFUEVD873A-01627?func=full-setset\&set_number=022855\&set_entry=000001\&format=999)

64. Woods P. La escuela por dentro: la etnografia en la investigacion educativa. Paidós. 1987. (https://www.scribd.com/document/405689363/Woods-P1987-La-escuela-por-dentro-la-etnografia-en-la-investigacion-educativa-pdf)

65. Sandoval C. Investigación cualitativa. Programa de especialización en teoría, métodos y técnicas de investigación social. ICFES: Bogotá; 2002. (https://panel.inkuba.com/sites/2/archivos/manual\%20colombia\%20cualitativo.pdf)

66. Malinowski B. Los argonautas del Pacífico Occidental: comercio y aventura entre los indígenas de la Nueva Guinea Melanésica. Ediciones Península; 2001. (http://eva.fhuce.edu.uy/file.php/194/63654554-Los-Argonautas-Del-Pacifico-Occidental-Vol-1-Bronislaw-Malinowski.pdf)

67. De Munck VC, Sobo EJ. Using methods in the field: a practical introduction and casebook. Rowman Altamira; 1998.

68. Bernard HR. Research methods in cultural Anthropology: qualitative and quantitative aproaches. Sage Publications, Inc. Newbury Park; 1988. (http://www.cycledoctoralfactec.com/uploads/7/9/0/7/7907144/\%5Bh._russell_bernard\%5D_research_methods_in_anthropol_bokos-z1_1_.pdf) 
69. Bernard RH, Ryan GW. Qualitative and quantitative methods of text analysis. Handbook of Research Methods in Cultural Anthropology. Printed in the United States of America; 1998.

70. Alexiades MN, Sheldon JW. Selected guidelines for ethnobotanical research: a field manual. 1996.

71. Lincon YS, Guba EG. Naturalistic Inquiry Sage Beverly Hills. CA; 1985.

72. Ryan GW, Nolan JM, Yoder PS. Successive Free Listing: Using Multiple Free Lists to Generate Explanatory Models. Field methods. 2000;12(2):83-107. (https://doi.org/10.1177/1525822X0001200201)

73. Weller SC, Romney AK. Systematic data collection (Volumen 10). Sage Publications, Inc. Newbury Park; 1988. (https://scholar.google.es/scholar? $\mathrm{hl}=$ es\&as_sdt=0\%2C5\&q=Weller+SC\%2C+Romney+AK.+Systematic+data+collection.+Sage+Publications\%2C+Inc.+Newbury+Park\%3B+1988.+\&btnG=)

74. Durkheim É. Las formas elementales de la vida religiosa: el sistema totémico en Australia (y otros escritos sobre religión y conocimiento). Fondo de cultura económica; 2012.

75. Tibuhwa DD. Folk taxonomy and use of mushrooms in communities around Ngorongoro and Serengeti National Park, Tanzania. J Ethnobiol Ethnomed. 2012;8(1), 36. (https://link.springer.com/article/10.1186/1746-4269-8-36)

76. Graeme KA. Mycetism: A Review of the Recent Literature. J Med Toxicol. 2014; 10:173-89. (DOI: 10.1007/s13181-013-0355-2)

77. Lincoff G, Mitchel DH. Toxic and hallucinogenic mushroom poisoning. A handbook for physicians and mushroom hunters. Van Nostrand Reinhold Company; 1977. (https://doi.org/10.1002/jobm.19800200324)

78. Harris M. El materialismo cultural. Madrid Alianza; 1982.

79. Estrada-Torres A, Aroche RM. Acervo etnomicológico en tres localidades del municipio de Acambay, Estado de México. Rev Mex Micol. 1987; 3,109-131. (https://www.scientiafungorum.org.mx/index.php/micologia/article/view/691)

80. Moreno Fuentes Á, Aguirre Acosta E, Pérez Ramírez L. Conocimiento tradicional y científico de los hongos en el estado de Chihuahua, México. Etnobiología. 2004;4(1):89-117.

(https://www.researchgate.net/publication/266488982_Conocimiento_tradicional_y_cientifico_de_los_hongos_en_el_estado_de_Chihuahua_Mexico)

81. Guzmán G. Los nombres de los hongos y lo relacionado con ellos en América Latina. introducción a la etnomicobiota y micología aplicada de la región, sinonimia vulgar y científica. Xalapa, Veracruz, México. Instituto de Ecología; 1997.

82. Guzmán-H. G. Sinopsis de los conocimientos sobre los hongos alucinógenos mexicanos. Boletín Soc Botánica México. 1959; $24: 14-34$. (file:///Users/amarantaramirez/Downloads/1058-Article\%20Text\%20(D0C\%20or\%20DOCX)\%20(Public\%20PDF)\%20-7229-2-10-20170316.pdf)

83. Wasson RG, Garrido F. El hongo maravilloso: Teonanácatl; Micolatría en Mesoamérica. Fondo de Cultura Económica; 1983.

84. Costa-Neto E, Santos-Fita D, Vargas-Clavijo M. Manual de Etnozoología. Valencia: Tundra; 2009. (https://www.researchgate.net/publication/324970730_Manual_de_Etnozoologia_una_guia_teoricopractica_para_investigar_la_interconexion_del_ser_humano_con_los_animales)

85. Zent EL. "We Come From Trees": The Poetics of Plants among the Jotï of the Venezuelan Guayana. J Study Relig Nat Cult. 2009;3(1). (DOI: 10.1088/1748-9326/8/1/015008)

86. Bautista-González JA. Conocimiento tradicional de hongos medicinales en seis localidades diferentes del país. Tesis de licenciatura, Universidad Nacional Autonóma de México; 2013. (http://oreon.dgbiblio.unam.mx/F/NCIVXKRFGEGCD2DEY72JKNGFGD4K9T4AK4EHAH7Y6JD3D123RP-48436?func=fullset-set\&set_number $=010643 \&$ set_entry $=000002 \&$ format $=999$ )

87. Michelot D, Melendez-Howell LM. Amanita muscaria: Chemistry, biology, toxicology, and ethnomycology. Mycol Res. 2003; 107(2):131-146. (https://doi.org/10.1017/S0953756203007305)

88. Turner NJ. "The Importance of a Rose": Evaluating the Cultural Significance of Plants in Thompson and Lillooet Interior Salish. Am Anthropol. 1988; 90(2):272-290. (https://doi.org/10.1525/aa.1988.90.2.02a00020)

\section{Tables}


Table 1. Nomenclature for non-edible mushroom ethnotaxa in the studied communities

\begin{tabular}{|c|c|c|}
\hline \multicolumn{2}{|c|}{ Ethnotaxon (names in Spanish, Nahuatl or both) } & \multirow[t]{2}{*}{ Scientific name } \\
\hline Francisco Javier Mina & San Isidro Buensuceso & \\
\hline Ajonjolinado & $\begin{array}{l}\text { Citlal-nanacatl } \\
\text { Literal transaltion: star-mushroom } \\
\text { Idiomatic translation: star mushroom }\end{array}$ & Amanita muscaria \\
\hline Amantecado venenoso* & $\begin{array}{l}\text { Tōtol-te-nanacatl de veneno } \\
\text { Literal translation: Turkey-rock-mushroom } \\
\text { Idiomatic translation: poisonous turkey egg mushroom }\end{array}$ & A. franchetii \\
\hline Amargo/amargoso* & $\begin{array}{l}\text { I-tlatla in caylita } \\
\text { Literal translation: her-double-of-caylita } \\
\text { Idiomatic translation: caylita's twin }\end{array}$ & Tricholoma virgatum \\
\hline Enchilado malo & $\begin{array}{l}\text { Chīl-nanacatl pitzō-nanacatl } \\
\text { Literal translation: chili/red-mushroom rabies } \\
\text { Idiomatic translation: pepper mushroom/red rabies mushroom }\end{array}$ & $\begin{array}{l}\text { Lactarius luculentus } \\
\text { Lactarius vinaceorufescens }\end{array}$ \\
\hline Clavo/clavito malo & Unknown & $\begin{array}{l}\text { Hygrocybe sp. } 1 \\
\text { Lyophyllum sp. } 2\end{array}$ \\
\hline Corneta de veneno & $\begin{array}{l}\text { Tlapitzal de veneno/ Tlapitzal venenoso/Tlapitzal malo } \\
\text { Literal translation: (article) trumpet } \\
\text { Idiomatic translation: poison/bad trumpet mushroom }\end{array}$ & $\begin{array}{l}\text { Phellodon niger } \\
\text { Sarcodon sp. } 1\end{array}$ \\
\hline $\begin{array}{l}\text { Corneta de veneno/corneta venenosa- } \\
\text { que no se come }\end{array}$ & $\begin{array}{l}\text { Cuā-te-caxnanacatl de veneno/Cuā-te-caxnanacatl malo/Cuā-te- } \\
\text { caxnanacatl que no se come } \\
\text { Literal translation: head-rock-mortar-mushroom } \\
\text { Idiomatic translation: poison/bad/inedible stone mortar (molcajete) } \\
\text { mushroom }\end{array}$ & $\begin{array}{l}\text { Lactarius mexicanus Lactarius } \\
\text { smithii } \\
\text { Russula densifolia }\end{array}$ \\
\hline $\begin{array}{l}\text { Escobeta de veneno/escobeta } \\
\text { venenosa-mala }\end{array}$ & $\begin{array}{l}\text { Xelhuāz nanacatl de veneno/Xelhuāz nanacatl malo } \\
\text { Literal translation: (article) fork-mushroom } \\
\text { Idiomatic translation: poison/bad fork mushroom }\end{array}$ & $\begin{array}{l}\text { Clavulina sp. } 1 \\
\text { Clavulina sp. } 2 \\
\text { Ramaria abietina } \\
\text { Ramaria gracilis }\end{array}$ \\
\hline Unknown & $\begin{array}{l}\text { Esquilon-nā-nanacatl de veneno } \\
\text { Literal translation: bell-duplication-mushroom } \\
\text { Idiomatic translation: poison bell mushroom }\end{array}$ & Clitocybe odora \\
\hline $\begin{array}{l}\text { Hongo de los palos podridos de } \\
\text { veneno }\end{array}$ & Unknown & $\begin{array}{l}\text { Agrocybe sp. } 1 \\
\text { Poliporoide sp. } 1 \\
\text { Trametes sp. } 1\end{array}$ \\
\hline $\begin{array}{l}\text { Paloma } \\
\text { Pancita venenosa* }\end{array}$ & $\begin{array}{l}\text { Unknown } \\
\text { Popozoh de veneno/Popozoh venenoso/Popozoh malo/Popozoh que } \\
\text { no se come/Popozoh-rabia } \\
\text { Literal translation: foam/venom } \\
\text { Idiomatic translation: poisonous foam }\end{array}$ & $\begin{array}{l}\text { Russula xerampelina } \\
\text { Suillus pseudobrevipes Suillus } \\
\text { tomentosus }\end{array}$ \\
\hline $\begin{array}{l}\text { Pante de veneno* } \\
\text { Pante morado* }\end{array}$ & $\begin{array}{l}\text { Xo-tomāh de rabia, veneno, } \text { mal }^{*} \\
\text { Xo-tomāh rabia** } \\
\text { Literal translation: foot-fat } \\
\text { Idiomatic translation: poisonous fat foot }\end{array}$ & $\begin{array}{l}\text { Boletus aff. bicolor } \\
\text { Boletus erythrophus } \\
\text { Boletus sp. } 1 \\
\text { Boletus sp. } 2 \\
\text { Xerocomellus chrvsenteron }\end{array}$ \\
\hline $\begin{array}{l}\text { Tecozah cimarrón } \\
\text { Tecozah de veneno/ Tecozah } \\
\text { venenosa } \\
\text { Tlapaltecozah de veneno } \\
\text { Unknown }\end{array}$ & $\begin{array}{l}\text { Te-cōzah de pitzō-nanacatl / } \\
\text { veneno/malo } \\
\text { Literal translation: rock-yello rabies } \\
\text { Idiomatic translation: rabitic yellow stone mushroom } \\
\text { Xocoyolitlnanacatl malo, de veneno } \\
\text { Literal translation: azadera-mushroom } \\
\text { Idiomatic translation: } \\
\text { bad yerba azadera mushroom }\end{array}$ & Hygrophoropsis aurantiaca \\
\hline Unknown & $\begin{array}{l}\text { Xōlētl de veneno } \\
\text { Literal translation: type of mushroom } \\
\text { Idiomatic translation: } \\
\text { poisonnous mushroom type }\end{array}$ & $\begin{array}{l}\text { Cortinarius sp. } 1 \text {; Gymnopus } \\
\text { dryophilus } \\
\text { Hygrocybe sp. } 1 \\
\text { Leucopaxillus sp. } 1 \\
\text { Lyophyllum decastes group } \\
\text { Lyophyllum sp. } 2 \\
\text { Pholliota sp. } 1 \\
\text { Psathyrella sp. } 1 \\
\end{array}$ \\
\hline
\end{tabular}


able 2. Cultural importance of the non-edible mushrooms present in studied communities

\begin{tabular}{l|l}
\hline Scientific names & Local name (in Nahuatl, Spanish or both) \\
\hline muscaria & $\begin{array}{l}\text { Citlal-nanacatl } \\
\text { ajonjolinado }\end{array}$
\end{tabular}

. erythropus

erocomellus

uillus pseudobrevipes . tomentosus

lavulina sp. 1 y sp. 2 amaria abietina - gracilis

. mexicanus

- aff. cinereoconia - xylinivolva

yophyllum sp. 2

. vinaceorufescens
Hongo-rado

Panté venenoso
xo-tomāh rabia

Popozoh venenoso

Popozoh de veneno

Escobeta de veneno

Xelhuāz Nanacatl de veneno

Corneta de veneno,

Cuā-te-caxnanacatl de veneno

Iztāc nanacatl de veneno

Enchilado malo

Chīl-nanacatl de pitzō-nanacatl, Chīl-nanacatl de veneno
Hongo blanco venenoso

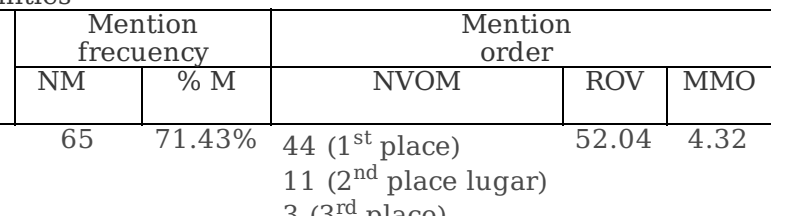

$3\left(3^{\text {rd }}\right.$ place $)$

4 ( $4^{\text {th }}$ place $)$

2 ( $5^{\text {th }}$ place $)$

$17^{\text {th }}$ place)

59

$64.83 \% 18$ (1 ${ }^{\text {st }}$ place)

17 ( $2^{\text {nd }}$ place)

9 ( $3^{\text {rd }}$ place)

9 ( $4^{\text {th }}$ place $)$

4 ( $^{\text {th }}$ place $)$

1 ( $^{\text {th }}$ place)

1 (15 $5^{\text {th }}$ place)

$24 \quad 26.37 \% \quad 3$ ( $1^{\text {st }}$ place)

6 ( $2^{\text {nd }}$ place)

7 ( $3^{\text {rd }}$ place)

1 ( $4^{\text {th }}$ place)

2 ( $5^{\text {th }}$ place)

2 ( $6^{\text {th }}$ place)

1 ( $^{\text {th }}$ place)

2 ( $^{\text {th }}$ place)

$2325.27 \% \quad 1$ (1 $1^{\text {st }}$ place)

3 ( $3^{\text {rd }}$ place $)$

6 ( $4^{\text {th }}$ place)

5 ( $5^{\text {th }}$ place)

2 ( $6^{\text {th }}$ place $)$

2 ( $^{\text {th }}$ place)

1 ( $8^{\text {th }}$ place)

1 ( $9^{\text {th }}$ place)

1 (12 $2^{\text {th }}$ place)

1 (14 ${ }^{\text {th }}$ place)

$17 \quad 18.68 \% \quad 3$ ( $2^{\text {nd }}$ place)

3 ( $3^{\text {rd }}$ place)

6 ( $4^{\text {th }}$ place)

1 ( $6^{\text {th }}$ place)

2 ( $7^{\text {th }}$ place)

1 (10 $0^{\text {th }}$ place)

1 (12 ${ }^{\text {th }}$ place)

1314.292 (2 13 place)

2 ( $4^{\text {th }}$ place)

3 ( $5^{\text {th }}$ place)

3 ( $6^{\text {th }}$ place)

2 ( $7^{\text {th }}$ place)

1 (10 $0^{\text {th }}$ place $)$

10

10.991 (1 ${ }^{\text {st }}$ place)

1 ( $3^{\text {rd }}$ place)

3 ( $4^{\text {th }}$ place)

$16^{\text {th }}$ place $)$

2 ( $7^{\text {th }}$ place)

1 (13 ${ }^{\text {th }}$ place)

1 (20 $0^{\text {th }}$ place)

9.719 .09

5.629 .58

4.649 .75

$2.99 \quad 10.24$

$2.66 \quad 10.42$

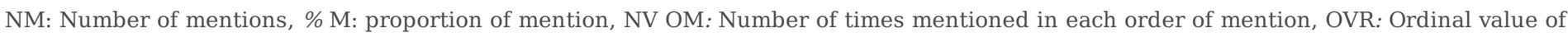
rank, MOM: mean order of mention.

\section{Figures}




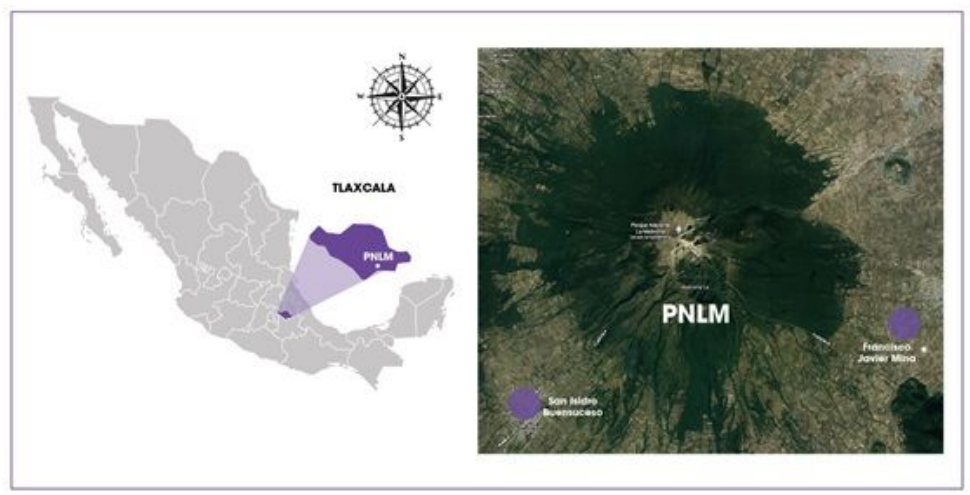

\section{Figure 1}

Study area. Purple dots indicate the communities in La Malintzi National Park who participated in the study and from which local knowledge concerning nonedible mushrooms was characterized
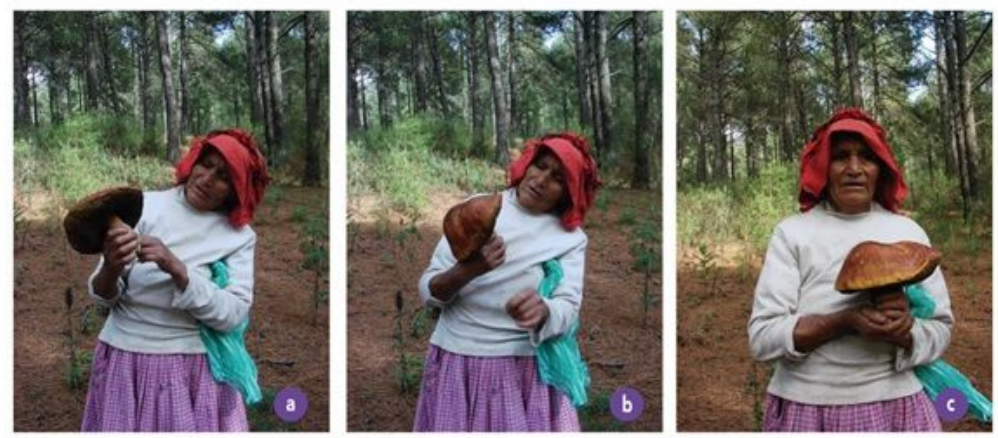

Figure 2

Non-edible mushrooms discriminating process stages. a. The specimen is carefully observed; one of its traits raises doubts. b. Said trait is verified. c. The specimen is confirmed as edible or rejected as inedible. Ms. Hermelinda holding a xo-tomāh. 


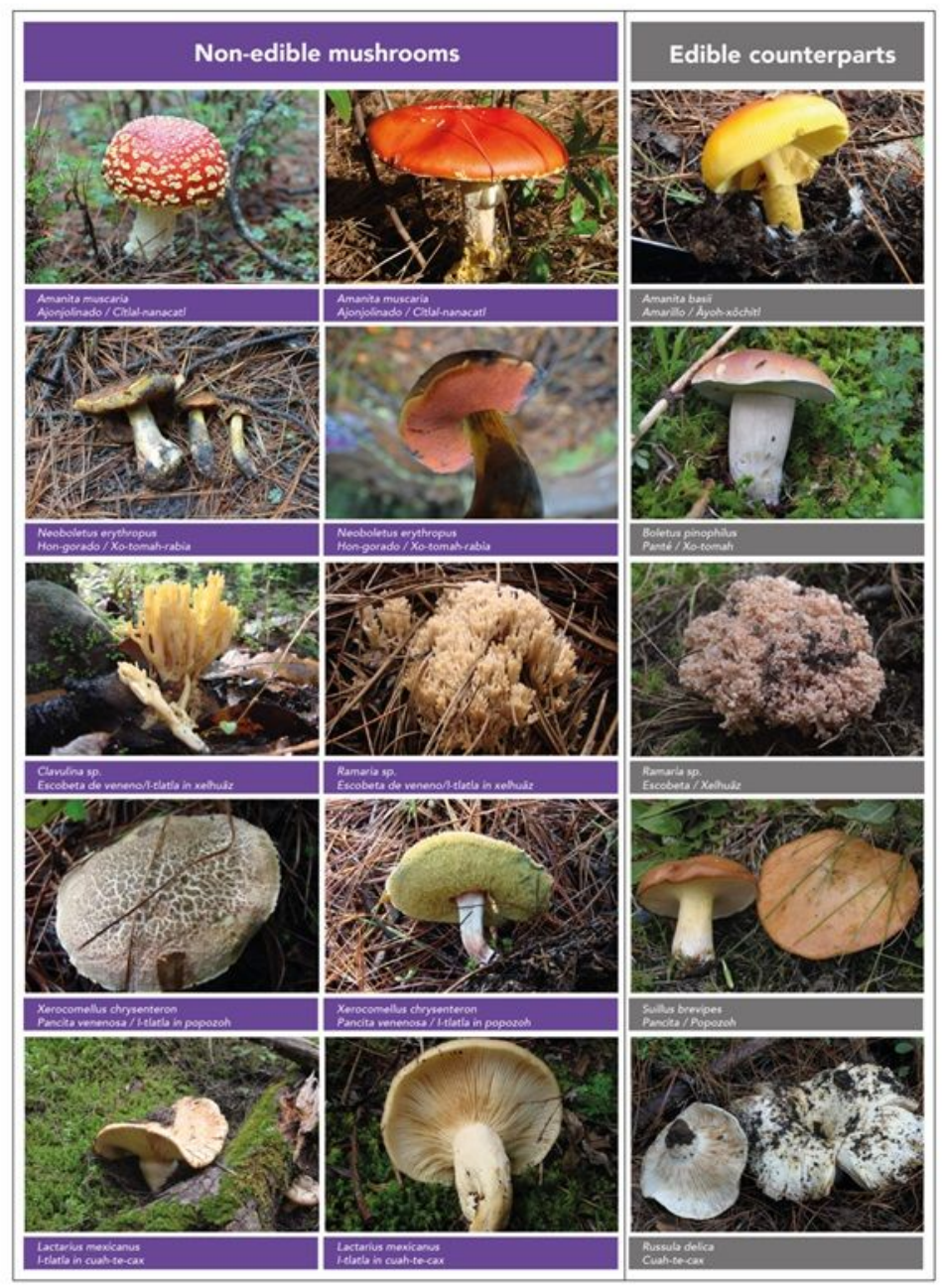

Figure 3

Examples of edible and non-edible mushrooms duality. 

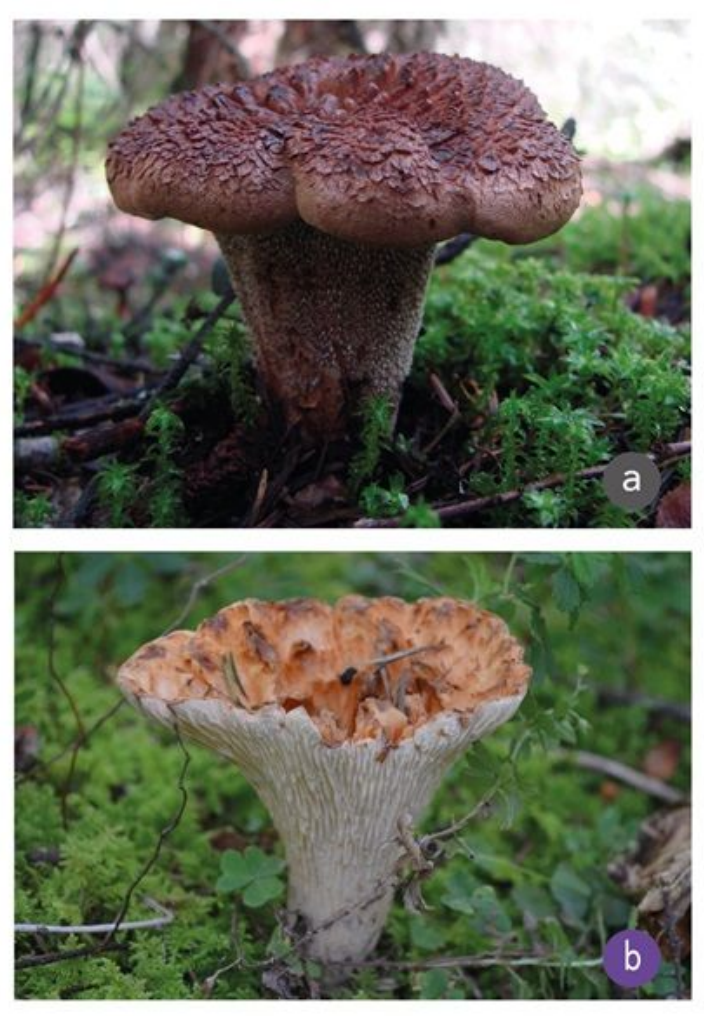

\section{Figure 4}

Identification of a non-edible mushroom by comparison with a similar edible counterpart. a. The Phellodon niger-Sarcodon sp. (in Nahuatl, I-tlatla in tlapītzal), is recognized by its unpleasant appearance, namely a distinct mix of colors (black, brown and purple), a dentate hymenium ("the underside is like a little brush") and very flaky scales ("the top of the cap doesn't look smooth, like it's rolling up"). b. Tlapitzal (T. floccosus) One of the most appreciated mushrooms in the San Isidro Buensuceso (SIBS) community.

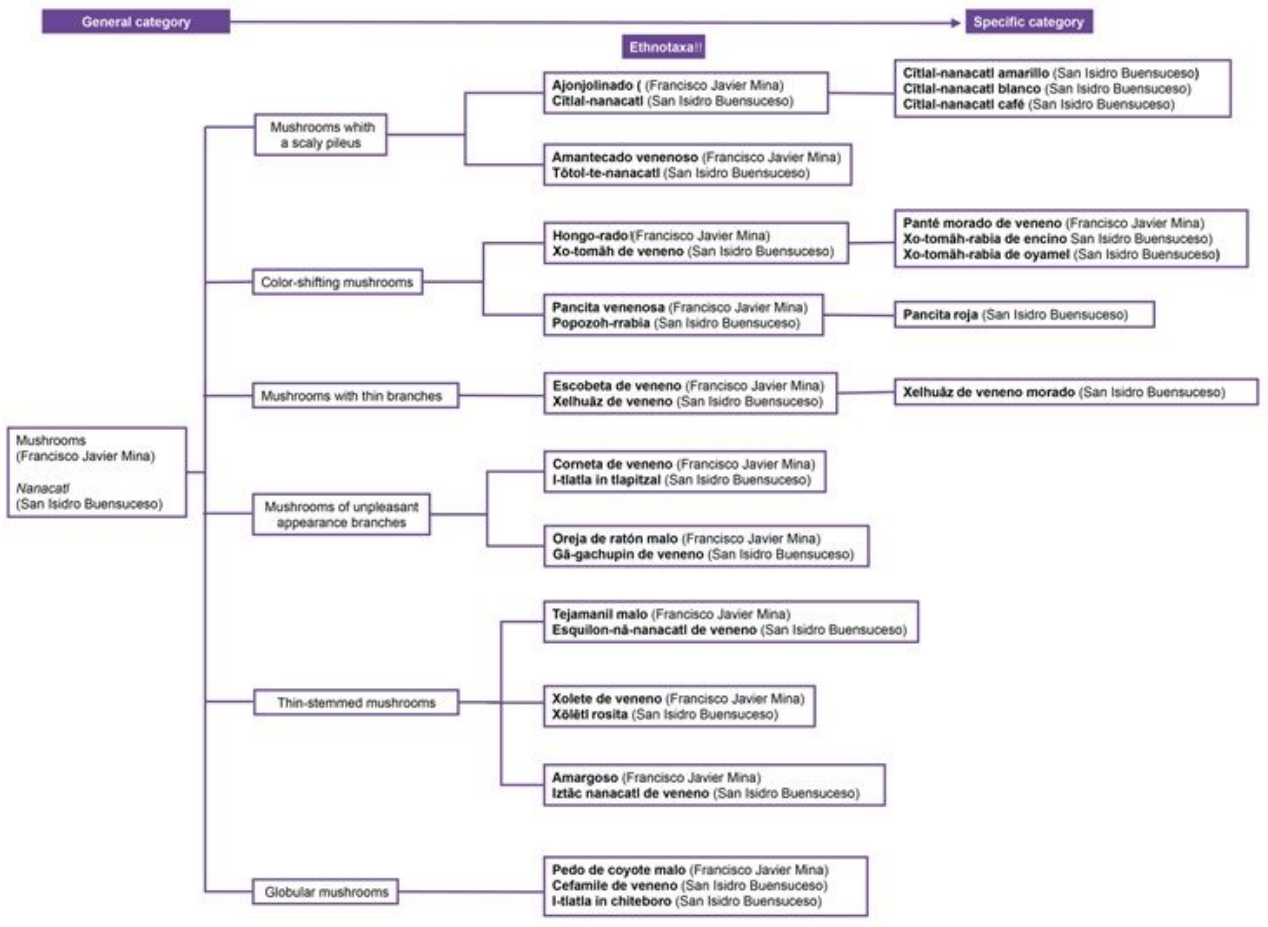

\section{Figure 5}

Hierarchical taxonomy of non-edible mushrooms 


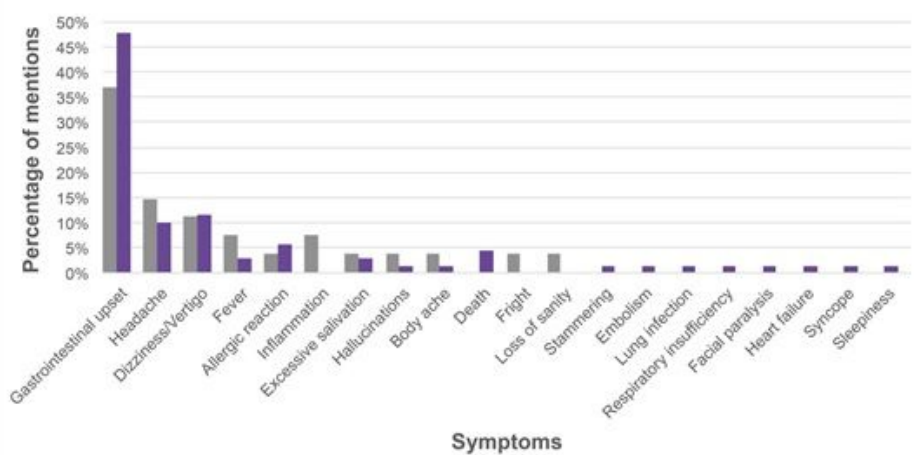

Figure 6

Non-edible mushroom consumption symptoms, by percentage of mentions

\section{The concept of non-edible mushroom vs poisonous mushroom}

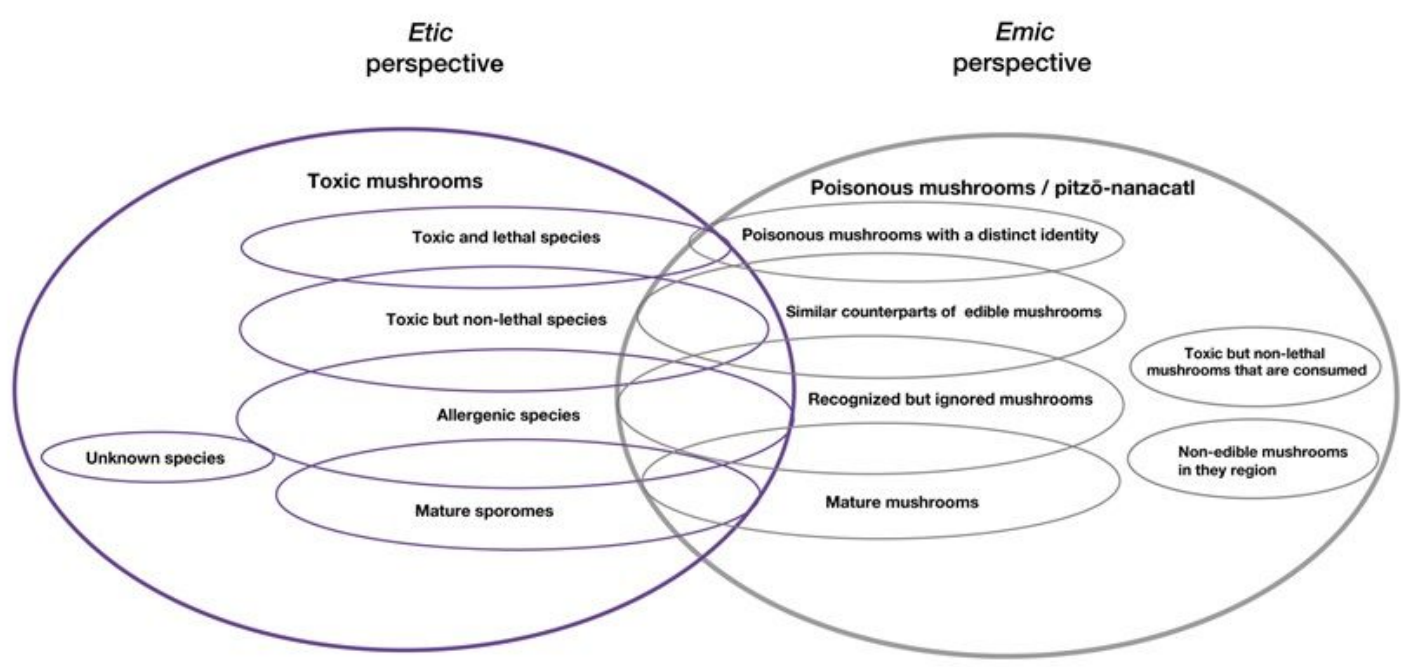

Figure 7

Representation of the concept of non-edibility in mushrooms from the perspective of etic vs emic 


\section{Non-edible mushrooms \\ (Poisonous mushrooms or pitzō-nanacatl)}

Unknow
$\begin{aligned} & \text { Cultural importance } \\ & \text { Scattered throughout the population } \\ & \text { Without! consensus } \\ & \text { Indicators of cultural importance for non-edible mushrooms: } \\ & \text { Relation to edible species } \\ & \text { Cosmovision } \\ & \text { Specific identifying characteristics } \\ & \text { Distinct identity } \\ & \text { Consensus name } \\ & \text { Specific name } \\ & \text { Intoxication risks } \\ & \text { Symptoms } \\ & \text { Consequences if consumed } \\ & \text { Uses } \\ & \text { Ecological factors (diversity and abundance) } \\ & \text { Frequency of mention } \\ & \text { Order of mention }\end{aligned}$

Figure 8

Non-edible mushrooms cultural importance indicators.

\section{Supplementary Files}

This is a list of supplementary files associated with this preprint. Click to download.

- AdditionalFile1.pdf

- AdditionalFile2.pdf 